\title{
WILLINGNESS TEST OF CONSUMERS TOWARD DISPOSAL OF
}

\section{WEEE}

\section{ZOFAIL HASSAN ${ }^{1, *}$ AND D.K.DHUSIA ${ }^{2}$}

1: Research Scholar, Department of Commerce and Business Studies, Jamia Millia Islamia, New Delhi

2: Associate Professor, Department of Commerce and Business Studies, Jamia Millia Islamia, New Delhi

*Corresponding Author: Zofail Hassan. S; E Mail: zofailhassan@gmail.com

Received $19^{\text {th }}$ July 2021; Revised $20^{\text {th }}$ Aug. 2021; Accepted $29^{\text {th }}$ Sept. 2021; Available online $1^{\text {st }}$ Nov. 2021 https://doi.org/10.31032/IJBPAS/2021/10.11.1008

\begin{abstract}
The purpose of the study is to generate insight into the pro-environmental customer's behavior toward sustainable disposal of WEEE and to examine the willingness of customers to pay recycling fees for proper disposal of WEEE. Government of India has promulgated a separate legislation for e-waste since 2011 however, onus on the household customers for proper disposal still in nascent stage. Instead of paying for proper disposal of WEEE they sell their end of life equipment to informal sector for some monetary gain and thereby promoting leakages of e-waste to the informal sector at every stage of channelization. Through parametric tests $\mathrm{T}$-tests and simple regression analysis it was ascertain that there is a significant difference between the pro-environmental behavior of the male and female respondents. Male respondents are willing to pay for recycling fee as compared to female respondents. Further, simple regression analysis showed that there is a significant relationship between income of the respondents and willingness to pay for recycling fee.
\end{abstract}

Keywords: Electrical \& Electronics Equipments (EEE), Waste Electrical \& Electronics

Equipments (WEEE), End of Life Equipment (EoL), Information Technology (IT) 


\section{INTRODUCTION}

India digital transformation has spurred in the demand for electrical and electronic equipment (EEE) in the country. The average life span of these electrical and electronic equipment (EEE) is decreasing day by day due to continuous innovation. When a user discards a device, it becomes waste electrical and electronic equipment (WEEE) which is one of the world's fastest growing waste streams with an annual growth rate between 4 to 5 per cent [1].

"This waste stream composed of almost any household or business use products like basic kitchen appliances, toys, tools to music, and information \& communication technology including mobile phones, laptops, computers, electric bulbs, and television sets" [2]. Preliminary research has estimated that waste electrical and electronic equipment (WEEE) composed of 1000 hazardous components which make it different from other wastes both physically and chemically [3-5]. The presence of hazardous materials poses a serious challenge in e-waste management. Developing countries including India faced with rising problem of e-waste stemming from both domestic generation and illegal import from developed [6]. Over the years the Government of India has promulgated of a separate policy for e-waste and implement EU directives which was perceived as serious effort in right direction, but the problem still persist. Even after the implementation extended producer responsibility, product stewardship, recycling and remanufacturing, the ground reality is that around ninety five percent of WEE are treated at the backyard by the informal recyclers using primitive techniques. Only five percent of e-waste being processed by formal sector. The informal sector constitutes a group of waste collector, middleman, scrap dealers and recyclers dealing with e-waste. Waste collectors piles up e-waste from customers through it strong network base and door to door services. After segregating they sells piles of WEEE to middlemen. The middlemen further sell it to scrap dealer and recyclers [7].

Thus, solely drafting of e-waste policy, extending the responsibility of proper management end of life equipment to producers of the product and routine vigilance on informal sector cannot address the growing menace of e-waste [8-11]. The emphasis should be given on disposal method of households customers who play an important role in the generation and management. For certain monetary gain the household customers sell their WEEE to informal sector thereby escalating the problem. Policy makers should put onus on the customer for proper disposal of e-waste and the customers should pay for recycling 
fee for their end of life equipment disposal.

Thus, the paper aims to investigate the proenvironmental behaviour of the customers and willingness of the customers to pay for recycling fee.

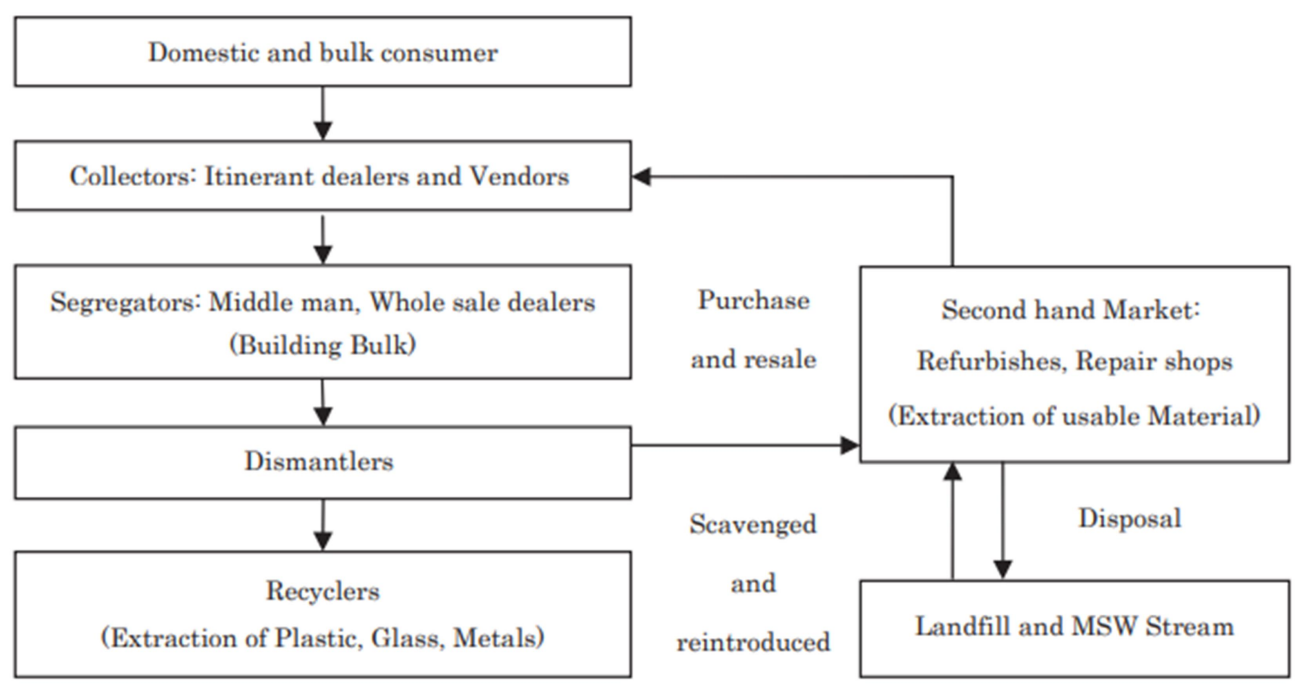

Figure 1: Informal processing of WEEE *Source: (N. Mahajan, 2014)

\section{REVIEW OF LITERATURE}

"Electrical and electronic equipment (EEE) such as cell phones, computers, video recorders, televisions, coffee machines, refrigerators and medical devices that add ease, comfort, and luxury to the modern life have become an indispensable part of modern societies [12]. Faster change of features in the electronics devices and availability of the improved products forcing the consumers to dispose the electronics products rapidly. This has caused generation of e-waste alarmingly. The major source of e-waste is the disposal of the hardware and electronic items from Government offices, public and private sectors, academic and research institutes. The household consumers are also contributing significant volume of end-oflife electronics products [13]. WEEE have emerged both as a global concern due to its massively high volume and health hazards associated with its improper handling, disposal, or recycling [13-14], the e-waste collected outside the formal system by individual waste companies or dealers is mostly processed and recycled under suboptimal conditions with primitive techniques and usually without any provisions to reduce the emission of hazardous chemicals into the environment informal recycling [15-16]. E-waste dumped into landfills or sold to peddlers often end up by polluting the environment through leaching into soil and groundwater, and via emission into the surrounding air, 
soil, and surface water [17-18]. E-waste is composed of various metals and non-metals which make its composition unique and diverse [19]. The appropriation, utilization, disposal, and recycling of e-waste affect many stakeholders in society, including households who play an important role in the generation and management of this waste stream [20, 21]. Due to some measure of ignorance in handling this waste stream, households face greater challenges in the disposal of e-waste than is the case with industrial enterprises and other institutions $[20,22]$. Thus, the extent to which households are informed and are aware of the problems associated with ewaste becomes an important factor that influences their 'utility maximizing decisions about the handling' of such wastes [23]. Sivanthanu [24] indicated that consumer awareness has a direct relationship with willingness to recycle ewaste, which is a crucial condition for efficient e-waste management. Furthermore, there are ineffective e-waste recycling efforts in developing countries such as Bangladesh and India because large proportions of their populations are relatively unaware about the precautionary measures necessary for handling and disposing e-wastes. However, literature also points out that households in these cities are willing to pay for the effective disposal of e-wastes [25- 27]".

\section{OBJECTIVE OF THE STUDY}

The proposed study focuses on the following objectives

1. To examine pro-environmental customers behavior toward sustainable disposal of WEEE

2. To investigate the willingness of customers to pay recycling fees for disposal of WEEE

\section{STUDY AREA, MATERIAL \& METHODS}

4.1 Study Area: The study was conducted in South Delhi. The area was selected because Nehru Place, India one of the biggest IT markets. Most of the electronic gadgets are bought and sold in this market at a discounted price. The key brands dealing in IT products found in this market. The markets has repair shop and sells discarded electronic goods in bulk.

\subsection{Survey Procedure and Sampling} Framework: The study is descriptive which aims at examining the proenvironmental behavior of the customers and to investigate willingness of customers to pay recycling fee for disposal of WEEE. Household customers visited the market for purchasing new Electric \& Electronic Equipment's (EEE) were prime target of the study. To ensure statistical creditability and data represent ability, Judgmental sampling procedure was adopted.

In total, 150 questionnaire were administered to the respondents out of 
which 120 responded, yielding a response rate of $80 \%$. The questionnaire were in English, however, when consumers faced difficulty in understanding the question then it was translated in local language 'Hindi'.

\subsection{Data Collection Method: The} quantitative primary data were collected through interviews. The questions were closed ended based on likert five point scale ranging from 'Strongly Disagree to Strongly Agree.' Considering the research ethic, the data were collected from the respondents after taking their oral consent.

The consent means that customers understood the purpose of the study and gave permission for the interview. The privacy and anonymity of the respondents were being protected.

4.4 Data Analysis: The data collected through primary survey were entered in MS excel version 2013. The data were further processed and coded. For descriptive and inferential analysis SPSS version 25 were used. The hypothesis are tested through Ttest and simple regression analysis.

\section{RESULT \& DISCUSSION}

\subsection{Demographic and Socio-Economic} Characteristic of Respondents

Table 1 presents the demographic and socio-economic characteristic of the respondents. Among 120 respondents, $74.8 \%(n=90)$ are males and $25 \%(n=30)$ are females. Males respondents were interviewed more compared to female counterpart, therefore it is unsurprising that females respondents

were underrepresented.

In the study majority of the respondents are in their early thirties $(55 \%, \mathrm{n}=66)$ and respondents above 60 years of age were $(5 \% ; n=6)$ which was the least. Most of the respondents had attained tertiary education qualification $(60 \% ; n=72)$ and only $(7 \%$; $\mathrm{n}=8.4$ ) were had no formal education.

The Table 2 shows the socio-economic condition of the respondents. On the basis of occupation respondents are classified as students, salaried and business. The representation of students respondents are $(42.5 \% ; \mathrm{n}=51)$ followed by salaried class $(38.33 \% ; \mathrm{n}=38.33)$ and Business class $(19.17 \% ; \mathrm{n}=23)$. Majority of the respondent earns upto 300,000 are $(47.5 \%$; $\mathrm{n}=57$ ). Most of them have a family size of $3-4(38.3 \% ; n=46)$.

\subsection{Independent $T$ - Test}

To examine pro-environmental behavior and willingness of customers to pay recycling fees for proper disposal of WEEE of male and female customers, T-test analysis was applied. Pro-environmental behavior was calculated through summated rating scale and score were calculated.

- $\mathbf{H}_{\mathbf{0}}$ : The mean score of male and female respondents are significantly same toward pro-environmental behavior and willingness of 
customers to pay recycling fees for proper disposal of WEEE.

- $\mathbf{H}_{1}$ : At least one of the mean score of male and female respondents are significantly different toward proenvironmental behavior and willingness of customers to pay recycling fees for proper disposal of WEEE.

Independent sample t-test was conducted to compare the mean score of male and female respondents toward proenvironmental behavior and willingness of customers to pay recycling fees for proper disposal of WEEE. Table 3 showcase the ttest result which states that there is a significant difference in mean score of male for pro-environment behavior $(\mathrm{M}=13.18$, S.D = 2.042), willingness to pay for recycling fee $(\mathrm{M}=13.92 .18, \mathrm{~S} . \mathrm{D}=3.700)$ and female for pro-environment behavior $(\mathrm{M}=9.53$, $\mathrm{S} . \mathrm{D}=1.252)$, willingness to pay for recycling fee $(\mathrm{M}=8.80$, S.D $=1.789)$ respondents.

\subsection{Simple Regression Analysis}

To investigate the relationship between willingness of customers to pay recycling fees for proper disposal of WEEE and income of the respondents' simple regression analysis was used to test the null hypothesis. Willingness to pay recycling fee was determined through summated rating scale ranging from 1 to 5 on likert scale.

The simple regression model is represented as $\mathrm{y}=\mathrm{b}_{0}+\mathrm{b}_{1} \mathrm{X}_{1}$, wherein $\mathrm{y}=$ outcome variable (willingness), $b_{0}=$ constant and $X_{1}$ $=$ independent variable (Income)

- $\mathbf{H}_{\mathbf{0}}$ : There is an insignificant prediction of income of the respondents and willingness of customers to pay recycling fees for proper disposal of WEEE.

- $\mathbf{H}_{1}$ : There is an significant prediction of income of the respondents and willingness of customers to pay recycling fees for proper disposal of WEEE.

The result presented in Table 4 shows that there is a significant relation between income of the respondents and willingness to pay recycling fee for proper disposal of e-waste. A significant regression equation was ascertained $(F(1,118)=284.69, p$ $<.000$, with an $\mathrm{R}^{2}$ of .704 . Respondents predicted willingness is equal to $5.824+3.280$ (Income) when income is measured in rupees. Respondents willingness to pay for recycling fee increased Rs 3.280 with every increase in the income of the respondents. Regression Equation can be formed as follows.

Willingness $=5.82+3.280$ Income 
Table 1: Demographic Profile of the respondents $(n=120)$

\begin{tabular}{|c|c|c|c|}
\hline Variables & Category & Frequency & Percentage (\%) \\
\hline \multirow[t]{2}{*}{ Gender } & Male & 90 & 75 \\
\hline & Female & 30 & 25 \\
\hline \multirow[t]{5}{*}{ Age } & $>\mathbf{3 0}$ & 27.61 & 23.01 \\
\hline & $>40$ & 66 & 55 \\
\hline & $>\mathbf{5 0}$ & 14.53 & 12.11 \\
\hline & $>60$ & 9.6 & 8 \\
\hline & $<60$ & 2.51 & 2.09 \\
\hline \multirow[t]{4}{*}{ Education Level } & No formal Education & 8.4 & 7 \\
\hline & Primary Education & 14.4 & 12 \\
\hline & Secondary Education & 25.2 & 21 \\
\hline & Tertiary Education & 72 & 60.12 \\
\hline
\end{tabular}

Table 2: Socio-economic of the respondents $(n=120)$

\begin{tabular}{|c|c|c|c|}
\hline Variables & Category & Frequency & Percentage (\%) \\
\hline \multirow[t]{3}{*}{ Occupation } & Student & 60 & 50 \\
\hline & Salaried & 40 & 33.33 \\
\hline & Business & 20 & 16.67 \\
\hline \multirow[t]{4}{*}{ Annual Income } & Upto 300000 & 57 & 47.5 \\
\hline & $300000-500000$ & 33 & 27.5 \\
\hline & $500000-1000000$ & 21 & 17.5 \\
\hline & Above 10000 & 9 & 7.5 \\
\hline \multirow[t]{5}{*}{ Family Size } & $1-2$ & 20 & 16.7 \\
\hline & $3-4$ & 46 & 38.3 \\
\hline & $5-6$ & 32 & 26.7 \\
\hline & $7-8$ & 14 & 11.7 \\
\hline & 9 Above & 8 & 6.67 \\
\hline
\end{tabular}

Table 3: T-test

\begin{tabular}{|c|c|c|c|c|c|c|}
\hline Variables & Gender & $\mathbf{N}$ & Mean & $\begin{array}{l}\text { Standard } \\
\text { Deviation }\end{array}$ & $\mathbf{t}$ & Significance \\
\hline \multirow{2}{*}{$\begin{array}{l}\text { Pro-Environmental } \\
\text { Behaviour }\end{array}$} & Male & 90 & 13.18 & 2.042 & \multirow[t]{2}{*}{10.40} & \multirow[t]{2}{*}{.000} \\
\hline & Female & 30 & 9.53 & 1.252 & & \\
\hline \multirow{2}{*}{$\begin{array}{l}\text { Willingness to pay for } \\
\text { recycling }\end{array}$} & Male & 90 & 12.92 & 3.700 & \multirow[t]{2}{*}{6.98} & \multirow[t]{2}{*}{.000} \\
\hline & Female & 30 & 8.80 & 1.789 & & \\
\hline
\end{tabular}

**Note: N: no. of respondents; t-value: pro-environmental behavior, willingness to pay for recycling, significance at p $<.05$ level

Table 4: Simple regression model

\begin{tabular}{|c|c|c|c|c|c|}
\hline & & $4:$ & & $\Gamma$ & 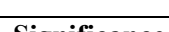 \\
\hline 1 Constant & $\begin{array}{c}\text { D } \\
5824\end{array}$ & \multirow{2}{*}{.704} & 1 & \multirow{2}{*}{284.689} & \multirow{2}{*}{.000} \\
\hline Income & 3.280 & & 118 & & \\
\hline
\end{tabular}

*Dependent variable- willingness, significance level at $\mathbf{p}<0.05$

VI. CONCLUSIONS

AND

\section{RECOMMENDATIONS}

Technological advancement and increasing consumerism in information society has led to growing amount of Electrical and Electronic Equipment (EEE). Customers are one of the important stakeholders in the generation of WEEE. So, it is crucial to understand their behaviour toward proper disposal after its useful life. The paper examines the pro-environmental behavior of the customers toward sustainable disposal of WEEE and their willingness to pay recycling fees. For the said purpose customers who regularly buy/uses electrical and electronic equipment (EEE) were investigated. The outcome of the results revealed that male respondents were significantly concerned toward sustainable disposal of WEEE. Most of male 
respondents were aware and concerned about the environmental impact of improper disposal of e-waste. They realize that EEE composed of hazardous chemical and it should not mix with any other waste. On the other hand female respondents although aware about the impact but they sell it to informal sector out of convenience, habits and for monetary gain. They assumes that it is responsibility of the government to keep the environment clean. The study also revealed that income of the customer plays significant role in willingness to paying for proper recycling fee. Customers whose annual income were above 10 lakhs were willing to pay for recycling fee while below 10 lakhs customers were reluctant to pay the recycling fee. They believe that already goods and services tax has increase the price of EEE and if recycling fee would be levied this would add extra cost to the product and the burden would fall on the customers. So, the recycling fee either be borne by producers or the government should take up the initiative of proper recycling. Thus, to keep a check on the growing menace of e-waste, the study recommend for setting up authorized collection centres. These centres should be responsible for collecting door to door ewaste even if a customer desire to discard single product. A toll free number should be provided by the collection centres wherein customer can prior book their ewaste as per their convenience and can hand over these end of life equipment on the specified date. This would prevent leakage of e-waste in informal sector and address the problem of inconvenience in disposal of e-waste by the customers. In addition, the authorized centres should provide coupons to the customer in exchange of WEEE this would address the issue of monetary gain. The customers can redeem coupons for purchase new or refurbished products at concessional rate. This would address the problem of monetary gain. Lastly, organizing awareness campaign mainly among the female customers would address the problem of traditional habit of selling end of life equipment to the informal sector.

\section{REFERENCES}

[1] Awasthi, A. K., \& Li, J. (2017). Management of Electrical and Electronic Waste: A Comparative Evaluation of China and India. Renewable and Sustainable Energy Reviews, 76, 434-447. https://doi.org/10.1016/j.rser.2017.0 2.067

[2] Baldé, C. P., Forti, V., Gray, V., Keuhr, R., \& Stegmann, P. (2017). The Global E-waste Monitor. United Nations University (UNU), International Telecommunication Union (ITU) \& International Solid 
Waste Association (ISWA),

Bonn/Geneva/Vienna.

[3] Khanna, R. (2018). Global Perspectives on regulatory measures and collection procedures for electronic waste: A critical assessment. Open Access Journal of Waste Management \& Xenobiotics, l(1).

https://doi.org/10.23880/oajwx16000101

[4] Lim-Wavde, K., Kauffman, R. J., \& Dawson, G. S. (2017). Household informedness and policy analytics for the collection and recycling of Household Hazardous Waste in California. Resources, Conservation and Recycling, 120, 88-107. https://doi.org/10.1016/j.resconrec.2 016.10 .007

[5] Liu, X., Tanaka, M., \& Matsui, Y. (2006). Electrical and electronic waste management in China: Progress and the barriers to overcome. Waste Management \& Research: The Journal for a Sustainable Circular Economy, 24(1), 92-101. https://doi.org/10.1177/0734242x06 062499

[6] Manomaivibool, $\quad$ P., $\quad$ \& Vassanadumrongdee, S. (2012). Buying back household waste electrical and electronic equipment:
Assessing Thailand's proposed policy in light of past disposal behavior and future preferences. Resources, Conservation and Recycling, 68, 117-125. https://doi.org/10.1016/j.resconrec.2 012.08 .014

[7] Niyati, M. (2014). Role of informal sector in e-waste recycling - core. Retrieved September 29, 2021, from https://core.ac.uk/download/pdf/144 446271.pdf.

[8] Tansel, B. (2017). From Electronic Consumer Products to e-wastes: Global Outlook, waste quantities, recycling challenges. Environment International, $\quad 98, \quad 35-45$. https://doi.org/10.1016/j.envint.201 6.10 .002

[9] Terada, C. (2012). Recycling Electronic Wastes in Nigeria: Putting Environmental and Human Rights at Risk. Northwestern Journal of Human Rights, 10(3), 154-172.

[10] Wang, W., Tian, Y., Zhu, Q., \& Zhong, Y. (2017). Barriers for household e-waste collection in China: Perspectives from formal collecting enterprises in Liaoning Province. Journal of Cleaner Production, 153, 299-308. https://doi.org/10.1016/j.jclepro.20 17.03.202 
[11] Zhan, L., \& Xu, Z. (2014). Stateof-the-art of recycling e-wastes by vacuum metallurgy separation. Environmental Science \& Technology, 48(24), 1409214102.

https://doi.org/10.1021/es5030383

[12] Ahirwar, R., \& Tripathi, A. K. (2021). E-waste management: A review of recycling process, environmental and occupational health hazards, and potential solutions. Environmental Nanotechnology, Monitoring \& Management, 15, 100409. https://doi.org/10.1016/j.enmm.20 20.100409

[13] Chatterjee, S. (2012). Sustainable Electronic Waste Management and Recycling Process. American Journal of Environmental Engineering, 2(1), 23-33. https://doi.org/10.5923/j.ajee.2012 0201.05

[14] Forti V., Balde C.P., Kuehr R., Bel G (2020). The Global E-waste Monitor 2020: Quantities, flows and the circular economy potential. United Nations University (UNU)/United Nations Institute for Training and Research (UNITAR) - co-hosted SCYCLE Programme, International Telecommunication Union (ITU) \&
International Solid Waste Association (ISWA), Bonn/Geneva/Rotterdam

[15] Chi, X., Streicher-Porte, M., Wang, M. Y. L., \& Reuter, M. A. (2011). Informal electronic Waste Recycling: A sector review with special focus on China. Waste Management, 31(4), 731-742. https://doi.org/10.1016/j.wasman.2 010.11 .006

[16] Pradhan, J. K., \& Kumar, S. (2014). Informal e-waste Recycling: Environmental risk assessment of heavy metal contamination IN Mandoli industrial area, Delhi, India. Environmental Science and Pollution Research, 21(13), 79137928.

https://doi.org/10.1007/s11356-

014-2713-2

[17] Cesaro, A., Belgiorno, V., Gorrasi, G., Viscusi, G., Vaccari, M., Vinti, G., Jandric, A., Dias, M. I., Hursthouse, A., \& Salhofer, S. (2019). A relative risk assessment of the open burning of weee. Environmental Science and Pollution Research, 26(11), 11042-11052.

https://doi.org/10.1007/s11356-

019-04282-3 
[18] Man, M., Naidu, R., \& Wong, M. H. (2013). Persistent toxic substances released from uncontrolled e-waste recycling and actions for the future. Science of The Total Environment, 463-464, 1133-1137.

https://doi.org/10.1016/j.scitotenv. 2012.07.017

[19] Rautela, R., Arya, S., Vishwakarma, S., Lee, J., Kim, K.-H., \& Kumar, S. (2021). Ewaste management and its effects on the environment and human health. Science of The Total Environment, 773, 145623. https://doi.org/10.1016/j.scitotenv. 2021.145623

[20] Wang, W., Tian, Y., Zhu, Q., \& Zhong, Y. (2017). Barriers for household E-waste collection in China: Perspectives from Formal Collecting enterprises in Liaoning Province. Journal of Cleaner Production, 153, 299-308. https://doi.org/10.1016/j.jclepro.20 17.03.202

[21] Manomaivibool, P., \& Vassanadumrongdee, S. (2012). Buying back household waste electrical and electronic equipment: Assessing Thailand's proposed policy in light of Past disposal behavior and future preferences.

Resources,

Conservation and Recycling, 68, 117-125.

https://doi.org/10.1016/j.resconrec. 2012.08.014

[22] Liu, X., Tanaka, M., \& Matsui, Y. (2006). Electrical and electronic waste management in China: Progress and the barriers to overcome. Waste Management \& Research: The Journal for a Sustainable Circular Economy, 24(1), 92-101.

https://doi.org/10.1177/0734242x0 6062499

[23] Lim-Wavde, K., Kauffman, R. J., \& Dawson, G. S. (2017). Household informedness and POLICY analytics for the collection and recycling of household hazardous waste in California. Resources, Conservation and Recycling, 120, 88-107. https://doi.org/10.1016/j.resconrec. 2016.10.007

[24] Sivathanu, B. (2016). User's Perspective: Knowledge and attitude toward's E-waste. International Journal of Applied Environmental Sciences, 11(2), 413-423.

[25] Ansari, N. L., Ashraf, M., Malik, T. B., \& Grunfield, H. (2010). Green IT awareness and practices: 
Results from a field study on mobile phone related e-waste in Bangladesh. In Proceedings of the 2010 IEEE International Symposium on Technology and Society, Wollongong, NSW, Australia, 375-383.

https://doi.org/10.1109/ISTAS.201

0.5514618

[26] Borthaku, A., \& Govind, M. (2017). Emerging trends in consumers' E-waste disposal behaviour and awareness: A worldwide overview with special focus on India. Resources, Conservation and Recycling, 117, 102-123.

https://doi.org/https://doi.org/10.1

016/j.resconrec.2016.11.011

[27] Grant, K., Goldizen, F. C., Sly, P. D., Brune, M.-N., Neira, M., van den Berg, M., \& Norman, R. E. (2013). Health consequences of exposure to e-waste: A systematic review. The Lancet Global Health, 1(6).

https://doi.org/10.1016/s2214109x(13)70101-3 